van Heyningen, W. E. (1959). J. gen. Microbiol. 20, 310-320

\title{
Tentative Identification of the Tetanus Toxin Receptor in Nervous Tissue
}

\author{
By W. E. vAN HEYNINGEN \\ Sir William Dunn School of Pathology, University of Oxford
}

\begin{abstract}
SUMMARY: The tetanus toxin receptor in nervous tissue appears to be a ganglioside (mucolipid, strandin, containing: fatty acid, sphingosine, glucose, galactose, acetylgalactosamine, acetylneuraminic acid and amino acid (?) residues). The watersoluble ganglioside occurs in nervous tissue in the form of labile water-insoluble complexes with cerebrosides and sphingomyelins. The solubility of the complexes in water increases with increasing ganglioside content, but decreases when calcium is incorporated. Standing with ganglioside inactivates the toxin.
\end{abstract}

In a previous paper (van Heyningen, $1959 a$ ) the specific receptor of tetanus toxin in the grey matter of nervous tissue was shown not to be a cerebroside, as had been thought by earlier workers (Landsteiner \& Botteri, 1906; Takaki, 1908), but a closely associated substance. Since attempts to isolate the receptor from crude cerebroside by extraction and adsorption invariably resulted in loss of receptor activity, it was decided to study the separation of the components of the crude material by counter-current distribution between immiscible solvents. As a preliminary to this it was necessary to devise a convenient in vitro assay of the receptor (van Heyningen, $1959 \mathrm{~b}$ ); this assay proved most useful in the work now reported, which led to the tentative identification of the receptor.

\section{METHODS}

The tetanus toxin preparations (XW1322, TD 464D), the antitoxin and the assay of toxin, the sphingolipid preparations and the method for suspending them in water, the assay of receptor and the method for estimating protein were described in earlier papers (van Heyningen, 1959 $a, b$ ). Ganglioside from brain was kindly supplied by Professor E. Klenk of the University of Cologne, and strandin by Dr J. Folch-Pi of Harvard University. Ganglioside was also prepared by the partition-dialysis method of Folch, Arsove \& Meath (1951) and by Rosenberg \& Chargaff's (1958) modification of this method. Ganglioside was estimated with Bial's reagent by the method of Bohm, Dauber \& Baumeister (1954), using Dr Folch-Pi's sample of strandin as a reference standard.

\section{RESULTS}

Initial failure to recover receptor in counter-current distribution experiments

The solvent system used in the first counter-current distribution experiment consisted of the two phases obtained when 20 vol. anhydrous methanol, 20 vol. $n$-hexane and 1 vol. water were mixed. When crude protagon was 
dissolved in equal volumes of the two phases and twenty-four transfers made in the counter-current apparatus, most of the dry weight was recovered in the first few tubes, but very little or no receptor could be recovered in any of the tubes. Similar results were obtained with the solvent system of Gregory \& Craig (1948; 15 vol. chloroform, 15 vol. benzene, 23 vol. methanol, 7 vol. water). However, when samples from all the tubes were pooled a high yield of receptor activity was obtained. Evidently the receptor was of complex constitution.

\section{Complex nature of the receptor}

Crude protagon was distributed between equal volumes of the two phases of the solvent system of Gregory \& Craig (1948), and the solvent evaporated from samples of each phase. The residues were weighed, suspended in water, the suspensions brought to the boil, cooled, and tested for receptor activity. $70 \%$ of the dry weight and only about $8 \%$ of receptor was recovered from the lower phase, and $30 \%$ of the dry weight and no receptor activity at all was recovered

Table 1. Recovery of receptor in two phases of Gregory \& Craig (1948) solvent system

$$
\text { RU = Receptor Unit, van Heyningen } 1959 b \text {. }
$$

$5 \mathrm{mg}$. protagon, before adding to $1 \mathrm{ml}$. lower phase $+1 \mathrm{ml}$. upper phase $\quad 65$

$3 \cdot 5 \mathrm{mg}$. lower phase material

$1.5 \mathrm{mg}$. upper phase material

$3.5 \mathrm{mg}$. lower phase material $+1.5 \mathrm{mg}$. upper phase material

Table 2. Upper and lower phase components must react together in solution to reconstitute receptor

$3.5 \mathrm{mg}$. lower phase component suspended in water

from the upper phase. However, when equal volumes of the two phases were mixed, the solvent evaporated off, and the residue suspended in water, an almost complete recovery of receptor activity was obtained. This is shown in Table 1. It appeared therefore that the receptor consisted of at least two components that were practically completely separated by partition between the two phases of the solvent system. That these components of the receptor were moieties of a complex, rather than cofactors, was suggested by the finding that when the material from each phase was independently suspended in water, and the two suspensions mixed, no receptor activity was recovered; but when the two components were added together in solution in organic solvent, the solvent removed and the residue suspended in water, full activity was recovered, as can be seen in Table 2. Apparently it was necessary that the two components should react together in solution in order to reconstitute the receptor. This suggestion was borne out by the fact that the upper phase 
component altered the appearance of the lower phase component. When a suspension of lower phase component was spun down the pellet was white, opaque and slightly granular; but the pellet from a suspension of protagon, or of the reconstituted complex, was translucent and gelatinous.

\section{The lower phase component}

Receptor activity was always associated with phrenosine, and the solubility properties of phrenosine were such that it was likely to appear in the lower phase of the Gregory \& Craig solvent system. An experiment was therefore done to test whether phrenosine and other cerebrosides could be substituted

Table 3. Replacement of lower phase component by phrenosine or mixed cerebrosides

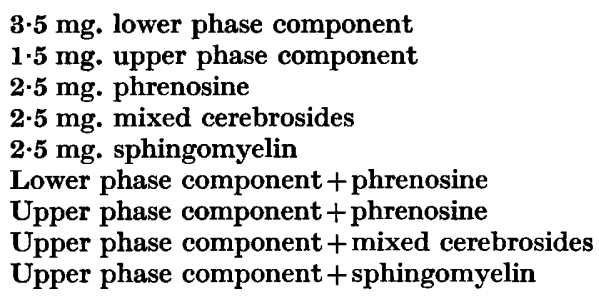

for the lower phase component. Table 3 shows that phrenosine could indeed be substituted for the lower phase component, but not the upper phase component, and purified mixed cerebrosides (phrenosine, cerasine, nervone) were as effective as phrenosine. In these tests sphingomyelin was apparently ineffective, but later work showed that this conclusion was misleading (see below).

In the experiments so far reported the chemical assay for receptor activity (van Heyningen, 1959 $b$ ) was used. Table 4 shows that the results obtained were confirmed with animal experiments. Phrenosine alone and upper phase

Table 4. Adsorption of protein and toxin from solutions containing $30 \mathrm{~L}+/ \mathrm{ml}$. by complex of phrenosine and upper phase component

\begin{tabular}{|c|c|c|c|}
\hline System & $\begin{array}{c}\text { Protein } \\
\text { adsorbed } \\
(\mu \mathrm{g} .)\end{array}$ & $\begin{array}{l}\mathbf{L}+\text { toxin } \\
\text { adsorbed }\end{array}$ & $\begin{array}{c}\text { Protein } \\
\text { per L+ } \\
\left(\mu \mathrm{g}_{\cdot}\right)\end{array}$ \\
\hline 0.5 mg. phrenosine & 18 & $\mathbf{0}$ & - \\
\hline $0.5 \mathrm{mg}$. upper phase component & $\mathbf{0}$ & $\mathbf{0}$ & - \\
\hline $\begin{array}{l}0.25 \mathrm{mg} \text {. phrenosine }+0.25 \mathrm{mg} \text {. upper phase } \\
\text { component }\end{array}$ & $\mathbf{1 5 5}$ & 80 & $\mathbf{1 . 9 4}$ \\
\hline
\end{tabular}

alone adsorbed little or no protein or toxin from a solution of crude toxin (XW 1322), but the complex of the two components adsorbed 1.94 $\mu \mathrm{g}$. protein for each $\mathrm{L}+$ unit of toxin. This ratio was in good agreement with the ratio 1.91 previously observed for the adsorption of toxic protein by protagon, and with the ratio of $2 \cdot 02-2 \cdot 15$ for pure crystalline toxin (see van Heyningen, $1959 b)$. 


\section{Formation of water-soluble complexes}

Occasionally complexes of phrenosine and upper phase component apparently failed to adsorb tetanus toxin, especially when the upper phase component had been partially purified by extraction with lower phase solvent. Figure 1, curves $a$ and $c$, show that this apparent failure to adsorb took place when more than a certain optimum proportion of upper phase component was present in the complex, and that the effect was more marked with partially purified upper

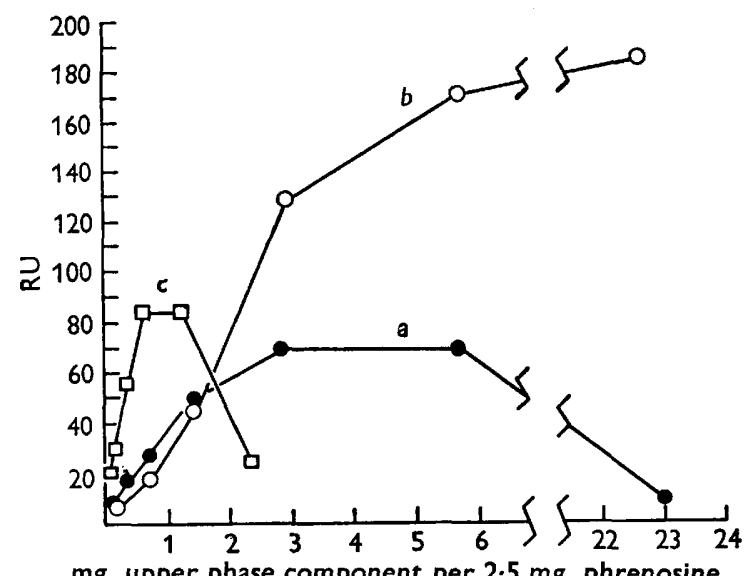

$\mathrm{mg}$. upper phase component per $2.5 \mathrm{mg}$. phrenosine

Fig. 1. Effect of varying proportions of upper phase component on activity of receptor complex. (a) Crude upper phase component from undialysed protagon. (b) Crude upper phase component from dialysed protagon. (c) Purified upper phase component from undialysed protagon.

phase component. At first it was thought that the effect was due to a watersoluble inhibitor contaminating the upper phase component, and this view appeared to be supported by the finding that there was no decrease of receptor activity with excess upper phase component prepared from an aqueous suspension of protagon that had been dialysed against tap water. However, it was then noticed that the spun-down pellets of receptor complex became progressively smaller as more upper phase component was incorporated, and correspondingly less toxin was carried down. Evidently the complexes became increasingly soluble in water with increasing content of upper phase component, and this was responsible for the apparent failure of the complex to adsorb toxin. Dialysing the protagon against tap water seemed to prevent this solubilization, possibly by introducing calcium into the complex, although partially purified upper phase component was soluble both in water and in $0.05 \mathrm{M}-\mathrm{CaCl}_{2}$ solution. Solutions of partially purified upper phase component in water, and in $0.05 \mathrm{M}-\mathrm{CaCl}_{2}$, were evaporated to dryness, dissolved in upper phase solvent, and added to solutions of phrenosine in lower phase solvent. The solvents were then evaporated off, the residues suspended in water, and the suspensions centrifuged in tared tubes, decanted, dried and weighed. Figure $2(a)$ shows that complexes containing cerebroside and more than a small proportion 
of upper phase component were progressively more soluble in water, but that incorporation of calcium in the complexes prevented them from becoming soluble. Calcium thus affected the solubility of the complex, but not of the upper phase component alone. Figure $2(b)$ shows that similar complexes were formed between upper phase component and sphingomyelin, and that these, with and without calcium, were more soluble than the cerebroside complexes.

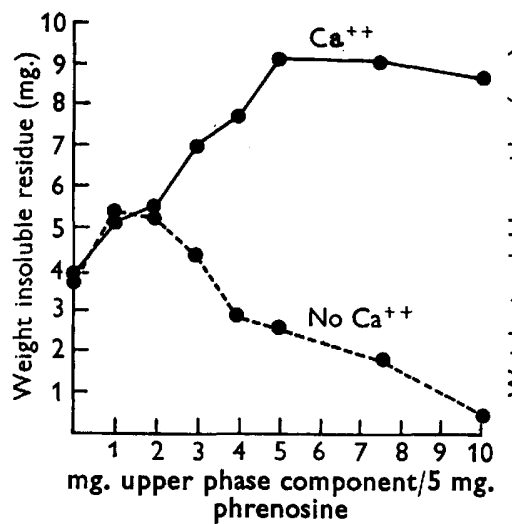

(a)

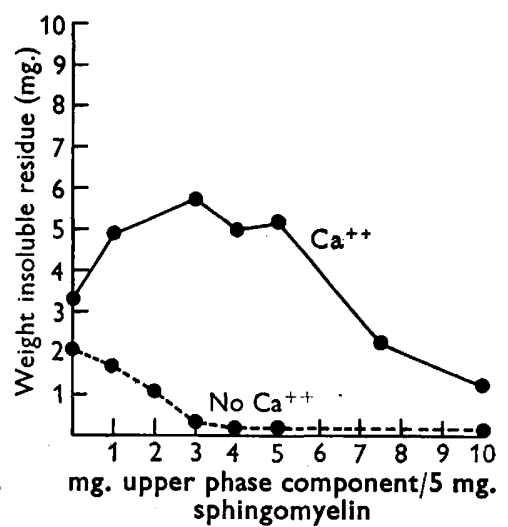

(b)

Fig. 2. Effect of varying proportions of upper phase component, and of calcium, on solubility of complexes with $(a)$ phrenosine, and $(b)$ sphingomyelin.

Since the assay for receptor activity (van Heyningen, 1959b) entails spinning out the receptor-toxin complex, it depends not only on the ability of the receptor to combine with toxin, but also on its insolubility in water and its ability to settle in the centrifugal field. Table 5 confirms the effect of calcium

Table 5. Effect of incorporation of calcium on ability of receptor complexes to carry down toxin

2.5 mg. upper phase
component with:
2.5 phrenosine
2.5 mg. sphingomyelin

$\overbrace{\begin{array}{cc}\text { No calcium } \\ 39 & \text { calcium } \\ 13 & 200 \\ 133\end{array}}^{\text {RU }}$

in apparently increasing the receptor activity of the complex of upper phase component and phrenosine. It shows further that the complex of upper phase component and sphingomyelin also fixed the toxin. The data in Table 3 had suggested that sphingomyelin could not replace the lower phase component of the receptor, but now it can be seen that this conclusion was erroneously drawn, because the sphingomyelin complex did in fact fix toxin, but, since it could not be spun down, the fixation was undetected.

\section{The upper phase component}

The water-insoluble lower phase component of the receptor complex occurs mainly in white matter, whereas the receptor occurs mainly in grey matter (van Heyningen, 1959a); it followed therefore that the water-soluble upper 
phase component should occur mainly in grey matter. The only lipids known to occur in greater concentration in grey matter $(0 \cdot 6-0.7 \mathrm{~g} . / 100 \mathrm{~g}$. fresh tissue) than in white matter $(0.06-0.07 \mathrm{~g} / 100 \mathrm{~g}$. fresh tissue; LeBaron \& Folch, 1957) are the water-soluble gangliosides (see Klenk, 1955), known also as strandin and mucolipids (Folch et al. 1951; see also Rosenberg \& Chargaff, 1958). The gangliosides probably exist in nature in several forms (see, for example, Svennerholm, 1956; Klenk, 1955). Strandin prepared from grey matter by

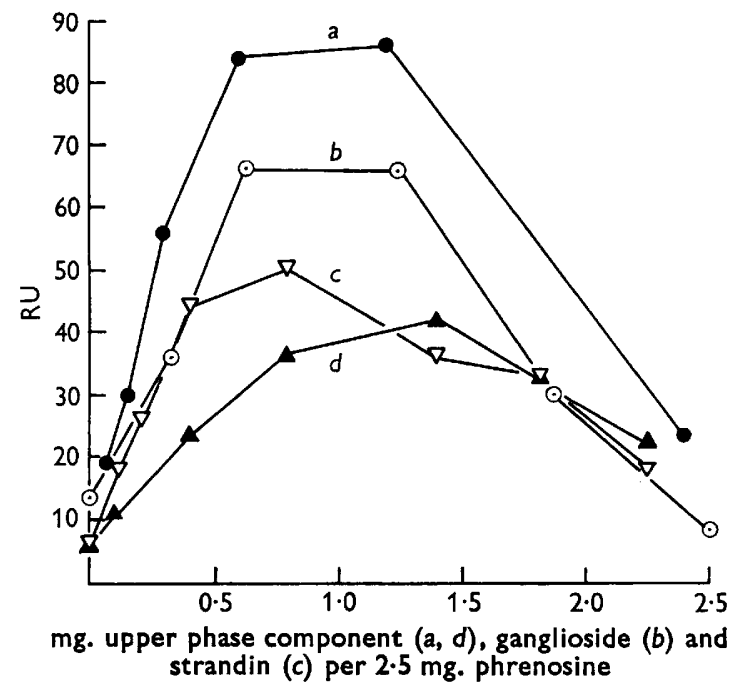

Fig. 3. Substitution of upper phase component $(a, d)$ by ganglioside $(b)$, and strandin $(c)$. Different samples of phrenosine used for $a, b$ and $c, d$.

gentle means (partition dialysis; Folch et al. 1951) can be obtained in a homogeneous form as judged by electrophoretic and ultracentrifugal criteria. It is a polymer of high molecular weight $(180,000)$ containing the following residues per molecule: fatty acid (mainly lignoceric), 101; sphingosine, 99; hexose (galactose and glucose in the ratio 8:1), $N$-acetylneuraminic (sialic) acid, 151; $N$-acetylgalactosamine, 36; amino acid, 58 (Rosenberg \& Chargaff, 1958). Brain ganglioside has a smaller molecular weight and contains the same residues as the polymer (except the amino acids), but only a fiftieth as many. It is probably derived from the polymer by acid hydrolysis, during the course of which the ratio of $\mathrm{N}$-acetylneuraminic acid to sphingosine residues falls from 1.5:1 to $1: 1$. In aqueous solution ganglioside aggregates to form particles of molecular weight $c .250,000$.

Besides occurring in greater concentration in grey matter than in white, the upper phase component had two further properties in common with gangliosides, viz. $(a)$ it was soluble in both water and organic solvents, and $(b)$ in the Bial test it yielded a pigment absorbing maximally at $570 \mathrm{~m} \mu$. Figure 3 shows that both strandin and ganglioside, tested with different samples of phrenosine, could be substituted for the upper phase component in the receptor complex. The quantitative differences between the curves obtained with the 
two different samples of phrenosine were probably due to differences in the solubilities of the resultant complexes, or in their ability to settle in the centrifugal field. As with upper phase component, incorporation of calcium prevented complexes containing equal weights of phrenosine and strandin (or ganglioside) from becoming water-soluble. Such complexes contained 40$50 \mathrm{RU} / \mathrm{mg}$., i.e. fixed an equal weight of toxin, since $1 \mathrm{RU}$ fixes $20 \mu \mathrm{g}$. toxin (van Heyningen, 1959b).

\section{Toxin fixation by ganglioside alone}

A ganglioside + cerebroside-Ca complex adsorbing toxin maximally contained roughly equal weights of ganglioside and cerebroside. The fatty acid, sphingosine and hexose residues of ganglioside probably comprise cerebroside moieties within the molecule (see Klenk, 1955; Rosenberg \& Chargaff, 1958). This raised the question of the function of the additional cerebroside with which it was necessary to unite the ganglioside in order to constitute the receptor, especially since sphingomyelin could be substituted for cerebroside. It seemed possible that the function of the cerebroside or sphingomyelin component might not be specific with respect to the toxin, but merely to render insoluble the otherwise soluble ganglioside component. The biological and chemical assays (van Heyningen, $1959 a, b$ ) could not be carried out unless the toxin receptor were insoluble in water and therefore removable by centrifugation at $5600 \mathrm{~g}$. The specific affinity of the toxin might be directed to the ganglioside moiety and independent of the cerebroside or sphingomyelin moiety. If the toxin were fixed by the ganglioside alone the resultant complex should be water-soluble, but should have a high molecular weight $(>200,000)$ and sediment rapidly in the ultracentrifuge. The following experiment was therefore carried out. In each of two Spinco model $L$ ultracentrifuge tubes were placed $3.25 \mathrm{ml}$. toxin solution containing $40 \mathrm{~L}+/ \mathrm{ml}$. 0.133 $\mathrm{M}$-phosphate buffer (pH 7). To one tube was added $3 \cdot 25 \mathrm{ml}$. water, to the other $3 \cdot 25 \mathrm{ml}$. of a solution containing $2 \mathrm{mg}$. ganglioside $/ \mathrm{ml}$. water. The contents of the tubes were mixed and centrifuged at $114,400 \mathrm{~g}$ for $2 \mathrm{hr}$. At the end of this time the centrifuge was stopped without the brake, the tubes removed without disturbing their contents, and the top $3.25 \mathrm{ml}$. of each withdrawn and the bottom $3.25 \mathrm{ml}$. stirred up. The top and bottom halves of the contents of the tubes were then assayed for toxin and, where appropriate, for ganglioside. The results are shown in Table 6. In the control tube containing toxin alone about $40 \%$ of the toxin in the upper half of the tube migrated to the lower half, where it all could be accounted for. In the tube containing ganglioside, less than $15 \%$ of toxin remained in the upper half, but no more toxin was recovered in the lower half than in the control tube. The experiment was repeated several times, always with the same result. The ganglioside thus appeared to carry the toxin down from the upper half of the tube; but the incomplete recovery of toxin was unsatisfactory. It was then found that incomplete recovery of toxin was probably due to inactivation by the ganglioside. Table 7 shows that when toxin was stood for $3 \mathrm{hr}$. ( $\mathrm{pH}$ constant at 7 ) with ganglioside it was $50 \%$ inactivated. The inactivation took time, was greater at $37^{\circ}$ than at $1^{\circ}$, and was not increased by 
increasing the ganglioside concentration from 1 to $5 \mathrm{mg} . / \mathrm{ml}$. Ganglioside and strandin were equally effective.

Since the movement of toxin in the ultracentrifugal field could not be followed by measuring the toxin by biological assay, it was decided to follow the movement of protein. For this purpose the toxin preparation TD 464D,

Table 6. Effect of ganglioside on ultracentrifugation of tetanus toxin

Recovery of toxin in upper and lower halves of centrifuge tubes after centrifugation for $2 \mathrm{hr}$. at $114,400 \mathrm{~g}$.

\begin{tabular}{|c|c|c|c|c|}
\hline & \multicolumn{4}{|c|}{$\%$ Recovery } \\
\hline & \multicolumn{2}{|c|}{ Ganglioside } & \multicolumn{2}{|c|}{ Toxin } \\
\hline System & $\begin{array}{c}\text { Upper } \\
\text { half }\end{array}$ & $\begin{array}{c}\text { Lower } \\
\text { half }\end{array}$ & $\begin{array}{c}\text { Upper } \\
\text { half }\end{array}$ & $\begin{array}{c}\text { Lower } \\
\text { half }\end{array}$ \\
\hline Toxin + water & - & - & $\mathbf{3 0}$ & 72 \\
\hline Toxin + ganglioside & $8 \cdot 3$ & $85 \cdot 0$ & $<7.5$ & 72 \\
\hline
\end{tabular}

Table 7. Inactivation of tetanus toxin by ganglioside

$\begin{array}{cccc}\begin{array}{c}\text { Conc. } \\ \text { ganglioside } \\ \text { (mg./ml.) }\end{array} & \begin{array}{c}\text { Time } \\ \text { (min.) }\end{array} & \begin{array}{c}\text { Temp. } \\ \left({ }^{\circ} \mathbf{C}\right)\end{array} & \begin{array}{c}\text { Inactivation } \\ \text { of toxin } \\ (\%)\end{array} \\ \mathbf{2} & 10 & 15 & 0 \\ 1 & 180 & 37 & 50 \\ 5 & 180 & 37 & 50 \\ 5 & 180 & 1 & 12 \\ 5 & 180 & \mathbf{3 7} & \mathbf{5 0} \\ 0 & 180 & 37 & 0\end{array}$

Table 8. Effect of ganglioside on ultracentrifugation of tetanus toxin (c. $75 \%$ pure) and pure lysozyme and trypsin

Recovery of protein and ganglioslde in upper and lower halves of centrifuge tubes after centrifugation for $2 \mathrm{hr}$. at $114,400 \mathrm{~g}$.

\begin{tabular}{|c|c|c|c|c|c|}
\hline \multirow{3}{*}{ System } & \multirow[b]{3}{*}{$\begin{array}{c}\text { Ionic } \\
\text { strength }\end{array}$} & \multicolumn{4}{|c|}{ \% Recovery } \\
\hline & & \multicolumn{2}{|c|}{ Ganglioside } & \multicolumn{2}{|c|}{ Protein } \\
\hline & & $\begin{array}{l}\text { Upper } \\
\text { half }\end{array}$ & $\begin{array}{c}\text { Lower } \\
\text { half }\end{array}$ & $\begin{array}{c}\text { Upper } \\
\text { half }\end{array}$ & $\begin{array}{c}\text { Lower } \\
\text { half }\end{array}$ \\
\hline Toxin + water & $0 \cdot 15$ & - & - & $\mathbf{3 5} \cdot 6$ & $68 \cdot 8$ \\
\hline Toxin + ganglioside & $\begin{array}{l}0 \cdot 15 \\
0 \cdot 30\end{array}$ & $\begin{array}{l}8 \cdot 2 \\
8 \cdot 8\end{array}$ & $\begin{array}{l}94 \cdot 1 \\
94 \cdot 1\end{array}$ & $\begin{array}{l}9 \cdot 9 \\
9 \cdot 9\end{array}$ & $\begin{array}{l}94 \cdot 6 \\
86 \cdot 2\end{array}$ \\
\hline Lysozyme + water & $0 \cdot 15$ & 一 & - & $34 \cdot 8$ & $\mathbf{5 3 \cdot 2}$ \\
\hline Lysozyme + ganglioside & $\begin{array}{l}0 \cdot 15 \\
0 \cdot 30\end{array}$ & $\begin{array}{l}9 \cdot 2 \\
9 \cdot 5\end{array}$ & $\begin{array}{l}82 \cdot 1 \\
95 \cdot 0\end{array}$ & $\begin{array}{l}29 \cdot 3 \\
37 \cdot 8\end{array}$ & $\begin{array}{l}69 \cdot 2 \\
67 \cdot 1\end{array}$ \\
\hline Trypsin + water & $0 \cdot 15$ & - & - & $38 \cdot 4$ & $62 \cdot 0$ \\
\hline Trypsin + ganglioside & $\begin{array}{l}0 \cdot 15 \\
0 \cdot 30\end{array}$ & $\begin{array}{l}9 \cdot 4 \\
8 \cdot 0\end{array}$ & $\begin{array}{l}87 \cdot 2 \\
95 \cdot 0\end{array}$ & $\begin{array}{l}35 \cdot 9 \\
37 \cdot 8\end{array}$ & $\begin{array}{l}67 \cdot 1 \\
62 \cdot 1\end{array}$ \\
\hline
\end{tabular}

which contained c. $75 \%$ toxic protein (van Heyningen, 1959b), was used. At the same time parallel measurements were made with crystalline lysozyme and crystalline trypsin, proteins which are adsorbed on the receptor complex at low ionic strength $(<0.15$; e.g. phosphate buffer $(\mathrm{pH} 7)<0.067 \mathrm{M}$; van 
Heyningen, 1959b). Similar experiments were set up as those reported in Table 6, except that the protein in the upper and lower halves of the contents of each centrifuge tube was determined, rather than the $L+$ units (Table 8). In a centrifugal field of $114,400 \mathrm{~g}$ about $80 \%$ of the ganglioside in the upper half migrated to the lower half of the tube, and when toxin was mixed with ganglioside about $80 \%$ of the protein migrated, whereas only $29 \%$ of the protein migrated in the control tube containing toxin alone ganglioside had no effect on the migration of trypsin, and only a slight effect on the migration of lysozyme, which was abolished when the salt concentration was doubled. Evidently it is the ganglioside component which specifically fixes the toxin.

\section{DISCUSSION}

The tetanus toxin receptor in nervous tissue can be identified, tentatively at any rate, as a ganglioside. The ganglioside is water-soluble, but in nervous tissue it apparently exists in the form of insoluble complexes with water-insoluble cerebrosides and sphingomyelins (and possibly with other substances as well). It is possible that the receptor is not a ganglioside itself, but a contaminant accompanying it and resembling it in its solubility properties. If this were the case the contaminant would have a very high capacity to fix toxin since the highly purified strandin preparation provided by Dr Folch-Pi fixed double its weight of toxin under the conditions of testing. The constitution of the gangliosides has not yet been precisely defined, and is unlikely to be defined for some time. They form particles of high molecular weight, containing nearly 700 residues of six different kinds, and probably exist in nature in several different forms. The mucolipids of Rosenberg \& Chargaff (1958) differ from ganglioside in the important respect that they contain one more $\mathrm{N}$-acetylneuraminic acid residue for every two sphingosine residues, and it appears that this residue, but not the other two $N$-acetylneuraminic acid residues, may be split off by the action of neuraminidase. This is suggested by the finding of Rosenberg, Howe \& Chargaff (1956) that ganglioside did not inhibit influenza virus haemagglutination and was not attacked by neuraminidase, whereas a high-molecular mucolipid preparation did inhibit haemagglutination, and nearly a third of its $N$-acetylneuraminic acid was split off by neuraminidase. Tetanus toxin, however, does not distinguish between ganglioside and strandin, and fixation of the toxin is therefore apparently independent of the postulated enzymically-removable $N$-acetylneuraminic acid residue. It will be interesting to determine what is the smallest fragment of ganglioside that can still fix toxin.

The fact that tetanus toxin is slowly inactivated, as well as fixed, by ganglioside (or a contaminant) is interesting and probably important. This phenomenon has not yet been investigated in detail and further studies are in progress.

The formation of complexes between different brain lipids, held together by bonds weaker than covalent bonds, is to be expected (see LeBaron \& Folch, 1957), and the insoluble component of the ganglioside + cerebroside/sphingomyelin complex no doubt has an important biological function. This work 
shows that the formation of such complexes can lead to the insolubilization of soluble ganglioside, or alternatively, to the solubilization of insoluble cerebrosides and sphingomyelin.

The experiments on the interaction of the receptor and the toxin were done at toxin concentrations far greater than would be encountered in the course of natural infection. The total weight of ganglioside in the nervous tissue of a mouse (say $\mathbf{1 - 5} \mathrm{mg}$. ?) is many million times that of a lethal dose of toxin $\left(10^{-7} \mathrm{mg}\right.$.), but at the concentration of toxin in a mouse dying of a single lethal dose a much greater amount of ganglioside would probably be needed to fix that dose than would be necessary under the conditions of the receptor assay (at $800,000 \mathrm{LD}_{50} / \mathrm{ml}$. protagon fixes 50,000 times as much toxin as at $20 \mathrm{LD}_{50} / \mathrm{ml}$. [van Heyningen, 1959a]). Moreover, only a small proportion of the total ganglioside, e.g. part of that situated in the anterior horn cells of the spinal cord, need be involved in a fatal outcome.

What the significance is of the fixation of tetanus toxin by the receptor in nervous tissue is not yet clear. Since the discovery of the WassermannTakaki phenomenon sixty years ago it has been thought that the fixation of toxin was directly connected with its mode of action (e.g. see Fildes, 1929). The specificity (van Heyningen, 1959b) and affinity of the receptor for the toxin, the fact that the inhibitory synapses and receptor are both in grey matter, and the fact that large doses of toxoid inhibit fixation of the toxin as well as its lethal action (see Discussion, van Heyningen, 1959b), all support this idea. It is possible that the ganglioside is the susceptible substance of the toxin, and that combination between the toxin and the ganglioside may be the first step leading to the biochemical lesion underlying the characteristic pharmacological action of the toxin. Another possibility is that the receptor may be responsible for the adsorption of the toxin from the site of infection and its centripetal transport in the nerve trunks to its site of action in the spinal cord and brain, and for its selective concentration and localization within nerve cells. Recent evidence suggests that cerebrosides are situated mainly within the myelin sheaths and membranes of nerve cells and their fibres, whereas gangliosides are situated within the nerve cell bodies and their dendrites and axons (see Svennerholm, 1957). Although the overall concentration of ganglioside in nerve trunks is very small (Folch-Pi \& LeBaron, 1957), and the capacity of nerve trunks to fix toxin low compared with that of brain (Fulthorpe, 1956), the significant concentration of ganglioside may be within the axon. On the other hand, it has been suggested that the transport of toxin takes place in the space between the nerve fibres, not in the nerve fibres themselves, and to be actuated by pressure following movement of limbs (see Wright, 1955). The obvious question, whether the ganglioside undergoes any change after fixing the toxin, is at present being investigated.

The author, as always, owes much to the continuing and indispensable generosity of the Wellcome Research Laboratories; in particular he wishes to thank Miss Mollie Barr, Mrs Irene Batty, Dr C. G. Pope and Dr R. O. Thomson for preparations of tetanus toxoid and tetanus, diphtheria and $\mathrm{Cl}$. welchii types $\mathrm{A}, \mathrm{B}, \mathrm{C}$ and $\mathrm{D}$ toxins. He also wishes to thank the following: Dr R. A. Kekwick of the Lister Institute for 
samples of purified serum albumin and $\alpha$ - and $\beta$-globulins; Professor E. Klenk of the University of Cologne for samples of ganglioside and derivatives; Dr Herbert E. Carter of the University of Illinois for samples of phrenosine, mixed cerebrosides, sphingomyelin and various other sphingolipid preparations; Dr J. Folch-Pi of Harvard University for samples of strandin; the slaughter house of the Oxford Co-operative Wholesale Society for co-operation in supplying beef brain and spinal cord; the Medical Research Council for a grant for expenses; his colleagues Dr A. M. Woodin and Dr S. P. Halbert for helpful discussions; Mr Jensen Otway for competent technical assistance; and Mrs Galatea Collins for kind non-technical assistance.

\section{REFERENCES}

Bohm, P., Dauber, S. \& Baumeister, L. (1954). Utber Neuraminsäure, ihr Vorkommen und ihre Bestimmung in Serum. Klin. Wschr. 32, 289.

Findes, P. (1929). In Medical Research Council: $A$ system of Bacteriology in Relation to Medicine, 3, 298. London: H.M. Stationery Office.

Folch, J., Arsove, S. \& Meath, J. A. (1951). Isolation of brain strandin, a new type of large molecule tissue component. J. biol. Chem. 191, 819.

Folch-Pi, J. \& LeBaron, F. N. (1957). Chemical composition of the mammalian nervous system. In Metabolism of the Nervous System, p. 67. Ed. D. Richter. London: Pergamon Press.

Fulthorpe, A. J. (1956). Adsorption of tetanus toxin by brain tissue. J. Hyg., Camb. 54, 315.

Gregory, J. D. \& Craig, L. C. (1948). Counter-current distribution of gramicidin. J. biol. Chem. 172, 839.

KLENK, E. (1955). The pathological chemistry of the developing brain. In Biochemistry of the Developing Nervous System, p. 397. New York: Academic Press Inc.

LANDSteiner, K. \& Botteri, A. (1906). Über Verbindungen von Tetanustoxin mit Lipoiden. IV. Z Zbl. Bakt. (Orig.), 42, 562.

LeBaron, F. N. \& Folch, J. (1957). Structure of brain tissue lipids. Physiol. Rev. 37, 539.

Rosenberg, A. \& Chargaff, E. (1958). A study of a mucolipide from ox brain. J. biol. Chem. 232, 1031.

Rosenberg, A., Howe, C. \& Chargaff, E. (1956). Inhibition of influenza virus haemagglutination by a brain lipid fraction. Nature, Lond. 177, 234.

Svennerholm, L. (1956). Composition of gangliosides from human brain. Nature, Lond. 177, 524.

SvenNerholm, L. (1957). Qnantitative estimation of gangliosides in senile human brains. Acta Soc. Med. Uppsala, 62, 1.

TAKakI, T. (1908). Ǔber Tetanusgift bindende Bestandteile des Gehirns. Beitr. chem. Physiol. Path. 11, 288.

van Heyningen, W. E. (1959 $a$ ). The fixation of tetanus toxin by nervous tissue. J. gen. Microbiol. 20, 291.

van Heyningen, W. E. $(\mathbf{1 9 5 9} b)$. Chemical assay of the tetanus toxin receptor in nervous tissue. J. gen. Microbiol. 20, 301.

Wright, G. P. (1955). The neurotoxins of Clostridium botulinum and Clostridium tetani. Pharmacol. Rev. 7, 413. 